\title{
FINGER AND PALMAR DERMATOGLYPHICS IN MUZEINA BEDOUIN FROM SOUTH SINAI: A QUANTITATIVE STUDY
}

\author{
BIBHA KARMAKAR ${ }^{1}$, EUGENE KOBYLIANSKY ${ }^{2}$ \\ ${ }^{1}$ Biological Anthropology Unit, Indian Statistical Institute, India \\ ${ }^{2}$ Human Population Biology Unit, Department of Anatomy and Anthropology, Sackler \\ Faculty of Medicine, Tel Aviv University, Israel
}

\begin{abstract}
Quantitative finger and palmar dermatoglyphics of 218 individuals (170 males and 48 females) belonging to the Muzeina Bedouins from South Sinai Peninsula. They are characterized with a high degree of consanguinity, a small isolate nomadic tribe. 22 quantitative dermatoglyphic traits (12 finger and 10 palms) were considered in the present study. Except PII (non-significant sex difference), the results of significant sex-differences of finger ridge counts (TFRC), MLI are similar with the earlier studies in various populations. However, the results of palmar traits reveal homogeneity which also presents a common picture obtained in the earlier studies perhaps, due to the possible role of environmental (prenatal) factors in the realization of dermatoglyphics between finger and palm. The development of palmar dermatoglyphics has a relatively longer growth period compared with fingers (Cummins 1929). Thus, the palmar dermatoglyphic pattern of affinities corresponds better than fingers to the ethno- historic background of the populations (Reddy et al. 1988, Karmakar et al. 1989, 2002, 2008, 2010).
\end{abstract}

Key words: Dermatoglyphics, pattern types, Bedouins 


\section{INTRODUCTION}

Several studies had demonstrated that dermatoglyphics are phylogenetically more stable than other biological traits (Rothhammer et al. 1977, Froehlich and Giles 1981). The fact that dermatoglyphic traits appear to be evolutionarily conservative renders them more reliable for studies of the historical relationships of population components. Dermatoglyphic character has also been suggested by Singh 1978 as the result of a biogenetic expression, rather than physical environment, because dermatoglyphic features are formed before the $19^{\text {th }}$ week of gestation (Penrose and Ohara 1973) and thereafter are not amenable to change due to age and/or environmental factors. Dermatoglyphic characteristics thus permanently preserve an earlier stage of fetal development, whereas most other biological characteristics are examined through postnatal development. Thus, due to these important characteristics, fingerprint patterns first attracted the interest of workers (see among others, Chakraborty et al. 1982; Karev 1991; Singh 1985; Devi 2000; Sengupta and Karmakar 2004; Karmakar et al. 2005, 2008, 2011). It was also found long ago that the application of proper statistical techniques, the genetics of quantitative aspect of dermatoglyphics could be better demonstrated than the qualitative traits (see among others, Bonnevie 1924; Newman 1930; Geipel 1941; Holt 1968; Matsuda 1973; Singh 1979, Dittmar 1994). Furthermore in general, the relative contribution of genetic and environmental factors to the phenotypic variation of dermatoglyphics differs from population to population (Cummins and Midlo 1961, Holt 1968, Kobyliansky et al. 1986, Kobyliansky and Livshits 1986, Arrieta et al. 1987, Karmakar et al 1989, Kobyliansky 1990, Crawford and Daggirala 1992, Jantz et al. 1993, Demarchi et al. 1997).

In view of the well-known ethnic diversity of the populations from different geographic areas, the main objective of the present article is (a) to provide information of quantitative finger and palmar patterns in a small isolate with a high degree of consanguinity, the nomadic tribe Muzeina Bedouins from South Sinai Peninsula and (b) to compare the present result with our previous studies on Indian populations (Karmakar et al 2002a, b), the Chuvashian population of Russia (Karmakar et al 2007, 2008) and Turkmenian populations (Karmakar and Kobyliansky 2010). 


\section{MATERIALS AND METHODS}

\section{Sample and the analyses of prints}

For centuries the Muzeina tribe inhabited the Sinai desert, which was especially occupied by the Bedouins and they originated mainly from the Saudi Arabian Peninsula (Hershkovitz 1985). The Muzeina tribe is characterized by strong biological isolation, rarely the intermix and shows preference for first-cousin marriages. The frequency of such marriages is $15 \%$ and the inbreeding coefficient is 0.09 . The sample contains data of 218 individuals ( 170 men and 48 women).

Finger and palmar prints were collected using the ink and roller method of Cummins \& Midlo (1961). The prints were mostly evaluated following Cummins \& Midlo (1961) and Holt 1968. Dermatoglyphic traits include the total of 22 quantitative traits- 12 finger and 10 palms were considered in the present study. Three types of finger patterns (UL, RL, and W) for finger ridge counts RC) on 10 fingers with total, absolute ridge counts and the pattern intensity index (PII); and on palm a-b ridge count, a-b distance, the main line index (MLI) and the mainline (A and D) terminations (MLT) were analyzed. All the types of true whorls like concentric, single spiral, double spiral, accidental, etc. and also all the types of composite whorls like twin loops, central pocket loops, lateral pocket loops, crested and knot-crested loops are grouped under the broad category of 'whorls'. On the other hand, radial and ulnar loops (RL and UL) were classified separately. The dermatoglyphic features were evaluated and presented for each sex and each hand separately in order to investigate both the sex and the bilateral differences.

The data were processed at the Tel Aviv University computer center, using the computer programs described by Nie et al., (1975). The phenotypic correlations between the studied finger ridge count variables were determined in males and females separately. One way analysis of variance was used to assess the statistical significance of the dermatoglyphic sex differences.

\section{RESULTS AND DISCUSSION}

\section{Finger Dermatoglyphics}

The pattern intensity index (PII) is little higher (Table 1) in females (15.03) than in males (14.72) with very small bilateral differences. PII values in our previous study (Karmakar et al. 2002a, b) in five Indian populations (ranging from 12.98 to 13.99 in males and 12.42 to 13.74 in females) differ significantly 
between males and females. This result is corroborated with earlier studies in diverse Jewish populations; they ranged from 14.07 to 14.50 in males and 12.93 to 13.42 in females (Cummins and Midlo 1927, Sachs and Bat Miriam 1957, Bat Miriam Katznelson and Ashbel 1973, Pereira et al. 1977), in the Chuvashian population (Karmakar et al. 2008). However, the present results of sex difference in PII are contradicted with all the above-mentioned earlier studies of diverse Jewish groups, Chuvashians as well as Indian populations. This difference may be due to a high degree of consanguinity of the nomadic tribe Muzeina Bedouins.

Table1. Pattern intensity index (PII) by hand and sex in Muzeina Bedouins

\begin{tabular}{lcccccc} 
& Mean & S.D. & C.V. & Mean & S.D. & C.V. \\
\hline Hand & \multicolumn{5}{c}{ Males } \\
\hline Left & 7.31 & 1.82 & 24.83 & 7.55 & 1.63 & 21.56 \\
Right & 7.43 & 1.77 & 23.86 & 7.41 & 1.45 & 19.63 \\
Both & 14.72 & 3.42 & 23.24 & 15.03 & 2.80 & 18.62 \\
\hline
\end{tabular}

Regarding the ridge count of pattern types in both sexes (Table2), the pattern type with the highest mean ridge count is whorl (18.62 in males, 17.53 in females), followed by the ulnar loop (14.12 in males, 14.07 in females), and the radial loop ( 8.88 in males, 12.32 in females), Similarly, the CV of pattern types increases from whorl to the ulnar loop and to the radial loop. The mean ridge count of a pattern of a given type is greater in males than in females (Table 3) for each finger with negligible differences. These results are similar to the above mentioned studies. The ridge counts of individual fingers are presented in Table 4. The mean ridge count of the first finger ( 21.75 in males, 20.01 in females) is invariably the highest among all the fingers, followed by the fourth finger (15.87 in males, 15.06 in females), which is in agreement with Karmakar et al. (2002a, b, 2008; Karmakar and Kobyliansky 2010). The lowest values belong to fingers II, III, and V. In all the fingers, the mean ridge count is greater in males than in females with very minimal differences in finger II. The CV of ridge counts is lower in fingers IV, V, and I and higher in fingers II and III, respectively and supports the above earlier findings. The total finger ridge count (TRC) is presented in Table 5. TRC is greater in males (160.81) than in females (155.96) for both hands, while C.V. is higher in females (24.02) than in males (22.56), may be due to a greater variability of pattern types in females, which corroborates the results of Kobyliansky and Micle (1988, 1989; 
Karmakar et al. 2008, Karmakar and Kobyliansky 2010). Therefore, we have the same interpretation as suggested in earlier studies (Kobyliansky and Micle $1983,1986)$ that the variability of TRC is conditioned by the frequencies of the same genes that are responsible for the presence of different finger pattern types.

Table 2. Ridge counts of finger pattern types by hand and sex in Muzeina Bedouins

\begin{tabular}{|c|c|c|c|c|c|c|}
\hline \multirow{2}{*}{ Hand } & Left & Right & Both & Left & Right & Both \\
\hline & \multicolumn{3}{|c|}{ Males } & \multicolumn{3}{|c|}{ Females } \\
\hline \multicolumn{7}{|c|}{ Ulnar loop } \\
\hline Mean RC & 14.09 & 14.15 & 14.12 & 13.42 & 14.62 & 14.07 \\
\hline S.D. & 5.29 & 5.68 & 5.48 & 5.64 & 5.89 & 5.80 \\
\hline C.V. & 37.57 & 40.16 & 38.85 & 41.99 & 40.28 & 41.20 \\
\hline Number & 487 & 475 & 962 & 161 & 189 & 350 \\
\hline \multicolumn{7}{|c|}{ Radial loop } \\
\hline Mean RC & 6.96 & 10.26 & 8.88 & 10.93 & 15.29 & 12.32 \\
\hline S.D. & 3.97 & 5.38 & 5.08 & 5.12 & 4.35 & 5.21 \\
\hline C.V. & 57.09 & 52.47 & 57.18 & 46.82 & 28.44 & 42.32 \\
\hline Number & 25 & 35 & 60 & 15 & 7 & 22 \\
\hline \multicolumn{7}{|c|}{ Whorl (max-count) } \\
\hline Mean RC & 19.01 & 18.22 & 18.62 & 17.72 & 17.34 & 17.53 \\
\hline S.D. & 4.70 & 4.91 & 4.82 & 4.52 & 4.46 & 4.49 \\
\hline C.V. & 24.72 & 26.92 & 25.88 & 25.51 & 25.73 & 25.60 \\
\hline Number & 503 & 505 & 1008 & 195 & 183 & 378 \\
\hline \multicolumn{7}{|c|}{$\operatorname{Arch}(\mathrm{RC}=0)$} \\
\hline Number & 22 & 14 & 36 & 7 & 6 & 13 \\
\hline
\end{tabular}

$\mathrm{RC}=$ Mean ridge count 
Table 3. Mean ridge counts of pattern types depended on pattern location on individual fingers by hand and sex in Muzeina Bedouins

\begin{tabular}{lccccccccccc}
\hline $\begin{array}{l}\text { Finger } \\
\begin{array}{l}\text { Pattern } \\
\text { types }\end{array}\end{array}$ & Mean & S.D. & Mean & S.D. & Mean & S.D. & Mean & S.D. & Mean & S.D. \\
\cline { 2 - 12 } \multicolumn{1}{c}{ Males } & & & & & & & & & & \\
\hline UL & 19.21 & 4.50 & 12.05 & 4.97 & 13.79 & 4.49 & 12.00 & 4.85 & 13.22 & 4.64 \\
\hline Left RL & - & - & 5.79 & 3.15 & 7.50 & 3.54 & 12.25 & 4.03 & - & - \\
\hline W & 23.21 & 4.22 & 16.65 & 4.29 & 17.88 & 3.87 & 18.25 & 4.02 & 17.59 & 3.89 \\
\hline & & & & & & & & & & \\
\hline UL & 20.35 & 5.30 & 12.39 & 5.06 & 13.48 & 4.42 & 12.15 & 4.73 & 11.83 & 4.44 \\
\hline Right RL & - & - & 9.62 & 5.74 & 9.00 & 4.24 & 13.20 & 4.21 & 12.50 & 2.12 \\
\hline W & 23.26 & 4.15 & 16.14 & 3.92 & 17.74 & 3.98 & 17.40 & 4.16 & 15.84 & 3.87 \\
\hline Females & & & & & & & & & & \\
\hline UL & 17.53 & 3.79 & 11.95 & 6.13 & 13.30 & 5.35 & 9.86 & 4.90 & 13.00 & 5.35 \\
\hline Left RL & - & - & 10.89 & 6.23 & 11.00 & 5.00 & 11.50 & 2.12 & 10.00 & - \\
\hline W & 20.72 & 4.28 & 16.52 & 4.11 & 17.50 & 5.39 & 17.30 & 3.73 & 15.63 & 3.80 \\
\hline & & & & & & & & & & \\
\hline UL & 20.08 & 4.88 & 13.02 & 4.76 & 14.50 & 5.05 & 10.00 & 5.37 & 12.25 & 5.78 \\
\hline Right RL & 20.00 & - & 17.00 & - & - & - & 15.25 & 4.03 & 9.00 & - \\
\hline W & 21.06 & 4.00 & 18.11 & 4.43 & 16.75 & 3.84 & 16.76 & 4.00 & 14.84 & 3.63 \\
\hline
\end{tabular}

Table 4. Ridge counts of individual fingers by hand and sex in Muzeina Beduins

\begin{tabular}{|c|c|c|c|c|c|c|c|c|c|}
\hline \multirow[t]{2}{*}{ Finger } & \multicolumn{3}{|c|}{ Left hand } & \multicolumn{3}{|c|}{ Right hand } & \multicolumn{3}{|c|}{ Both hands } \\
\hline & Mean & S.D. & C.V. & Mean & S.D. & C.V. & Mean & S.D. & C.V. \\
\hline \multicolumn{10}{|c|}{ Males } \\
\hline I & 21.50 & 4.77 & 22.17 & 21.96 & 4.91 & 22.35 & 21.75 & 4.41 & 20.27 \\
\hline II & 13.17 & 5.61 & 42.58 & 12.82 & 5.96 & 46.51 & 13.10 & 5.15 & 39.34 \\
\hline III & 14.86 & 5.04 & 33.90 & 14.56 & 4.82 & 33.12 & 14.66 & 4.47 & 30.47 \\
\hline IV & 16.14 & 5.37 & 33.27 & 15.78 & 5.11 & 32.38 & 15.87 & 4.81 & 30.32 \\
\hline $\mathrm{V}$ & 15.40 & 4.80 & 31.16 & 13.97 & 4.57 & 32.74 & 14.62 & 4.45 & 30.43 \\
\hline \multicolumn{10}{|c|}{ Females } \\
\hline I & 19.48 & 4.36 & 22.39 & 20.54 & 4.45 & 21.66 & 20.01 & 4.11 & 20.55 \\
\hline II & 13.51 & 5.89 & 43.61 & 14.08 & 6.26 & 44.49 & 13.66 & 5.49 & 40.21 \\
\hline III & 14.59 & 5.68 & 38.94 & 14.77 & 5.14 & 34.82 & 14.71 & 5.00 & 34.01 \\
\hline IV & 15.29 & 5.50 & 35.94 & 15.36 & 5.01 & 32.63 & 15.06 & 4.94 & 32.79 \\
\hline $\mathrm{V}$ & 14.41 & 4.70 & 32.61 & 13.78 & 4.71 & 34.20 & 14.05 & 4.33 & 30.83 \\
\hline
\end{tabular}


Table 5. Ridge counts of left, right and both hands by hand and sex in Muzeina Beduins

\begin{tabular}{lccccccccc}
\hline Sex & \multicolumn{3}{c}{ Left hand } & \multicolumn{3}{c}{ Right hand } & \multicolumn{3}{c}{ Both hands (TRC) } \\
\hline & Mean & S.D. & C.V. & Mean & S.D. & C.V. & Mean & S.D. & C.V. \\
Males & 82.24 & 19.31 & 23.48 & 78.44 & 18.84 & 24.01 & 160.81 & 36.27 & 22.56 \\
Females & 76.95 & 20.80 & 27.03 & 79.57 & 19.97 & 25.09 & 155.96 & 37.46 & 24.02 \\
\hline
\end{tabular}

Correlation coefficients between finger ridge counts are presented in Table 6 . The correlation ranged from 0.230 to 783 in males and from 0.241 to 0.826 in females. However, these coefficients of correlation are not similarly high ( 0.722 to 0.817 in males and 0.744 to 0.846 in females) as those obtained in other Jewish populations (Kobyliansky and Micle 1988, 1989) as well as in other populations (Holt 1959, 1968; Mavalwala 1962, Singh et al. 1977). The correlation ranged from 0.286 to 0.783 in males and from 0.292 to 0.776 in females in the Turkmenian population (Karmakar et al. 2010) are also similar with the present results. But the correlation ranged from 0.067 to 0.574 in males and from 0.119 to 0.592 , in females in the Chuvashian population (Karmakar et al. 2008) figures are lower than the above findings, it may be due to major ethnic differences.

Table 6. Correlation coefficients of finger ridge counts by sex and hand in Muzeina Bedouins

\begin{tabular}{lccccccccccc}
\hline \multirow{2}{*}{ Finger } & \multicolumn{4}{c}{ Left hand } & \multicolumn{1}{c}{ Right hand } \\
\cline { 2 - 11 } & V & IV & III & II & I & V & IV & III & II & I \\
\hline I & 0.374 & 0.248 & 0.261 & 0.230 & 0.681 & 0.340 & 0.271 & 0.301 & 0.290 & - \\
II & 0.505 & 0.517 & 0.546 & 0.646 & 0.420 & 0.501 & 0.462 & 0.619 & - & 0.477 \\
III & 0.537 & 0.633 & 0.649 & 0.569 & 0.367 & 0.570 & 0.650 & - & 0.677 & 0.407 \\
IV & 0.618 & 0.717 & 0.643 & 0.473 & 0.340 & 0.640 & - & 0.703 & 0.674 & 0.366 \\
V & 0.783 & 0.654 & 0.505 & 0.513 & 0.369 & - & 0.588 & 0.520 & 0.573 & 0.241 \\
I & 0.432 & 0.328 & 0.433 & 0.390 & - & 0.404 & 0.517 & 0.552 & 0.524 & 0.705 \\
II & 0.506 & 0.578 & 0.578 & - & 0.523 & 0.679 & 0.645 & 0.626 & 0.782 & 0.391 \\
III & 0.499 & 0.611 & - & 0.647 & 0.552 & 0.608 & 0.751 & 0.719 & 0.691 & 0.451 \\
IV & 0.636 & - & 0.826 & 0.580 & 0.493 & 0.572 & 0.794 & 0.696 & 0.651 & 0.387 \\
V & - & 0.552 & 0.531 & 0.705 & 0.496 & 0.787 & 0.480 & 0.527 & 0.615 & 0.315 \\
\hline
\end{tabular}

Males: Above and left of the diagonal.

Females: Below and right of the diagonal. 


\section{Palmar dermatoglyphics}

The main line index (MLI), angle 'atd' and a-b inter-digital ridge count are all presented in Table 7. The mean value of MLI for both hands in males (8.42, $9.12)$ is higher than in females $(8.24,8.57)$. There are slightly greater MLI values in the right hand than in the left one in both sexes, which reflects the transversality of the palmar main lines, and sex- differences are not significantly different. However, the angle 'atd' (88.89 in males, 91.43 in females) and a-b inter-digital ridge count (79.60 in males, 81.33 in females) shows slightly higher values in females than in males, which does not differ significantly. These results are corroborated to those of Jewish populations (Kobyliansky and Micle 1988), the Chuvashian population (Karmakar et al. 2008), the Turkmenian population (Karmakar et al. 2010) and Indian populations (Karmakar et al. 2002a, b).

Table 7. Means and standard deviations of palmar dermatoglyphic traits by hand and sex in Muzeina Beduins

\begin{tabular}{|c|c|c|c|c|c|}
\hline \multirow{2}{*}{ Trait } & \multirow[t]{2}{*}{ Hand } & \multicolumn{2}{|c|}{ Males } & \multicolumn{2}{|c|}{ Females } \\
\hline & & Mean & S.D. & Mean & S.D. \\
\hline \multirow{3}{*}{ Main line index } & Left & 8.42 & 1.92 & 8.24 & 1.72 \\
\hline & Right & 9.12 & 1.89 & 8.57 & 2.00 \\
\hline & Both & 8.79 & 1.76 & 8.39 & 1.69 \\
\hline \multirow{3}{*}{ atd angle (degrees) } & Left & 45.03 & 10.12 & 46.03 & 8.08 \\
\hline & Right & 44.10 & 8.46 & 45.39 & 7.95 \\
\hline & Both & 88.89 & 16.09 & 91.43 & 14.15 \\
\hline \multirow{3}{*}{$a-b$ ridge count } & Left & 40.53 & 6.74 & 41.81 & 6.33 \\
\hline & Right & 39.06 & 7.18 & 39.59 & 6.59 \\
\hline & Both & 79.60 & 12.71 & 81.33 & 11.71 \\
\hline \multirow{3}{*}{ a-b distance $(\mathrm{mm})$} & Left & 21.36 & 4.19 & 20.28 & 3.66 \\
\hline & Right & 20.94 & 3.99 & 19.84 & 3.94 \\
\hline & Both & 42.30 & 7.73 & 40.08 & 7.22 \\
\hline \multirow[t]{2}{*}{ Ridge breadth } & Left & 0.529 & 0.089 & 0.490 & 0.066 \\
\hline & Right & 0.519 & 0.087 & 0.475 & 0.062 \\
\hline
\end{tabular}




\section{Sex Comparison}

Table 8 presents the sex differences of 22 dermatoglyphic variables by the ANOVA test. The ridge counts on individual fingers regarding sex differences are mostly uniform between the right and left sides. Finger I shows a markedly significant difference (4.86 on right, 10.55 on left). Significant sex differences (4.03) appear for total (TFRC) finger ridge counts, the main line A and D terminations, but there are no significant differences on the palmar a-b ridge count. Thus, compared to the finger ridge count, the results of palmar traits

Table 8. Comparison of 22 quantitative dermatoglyphic traits and indices in males and females by ANOVA method in Muzeina Beduins

\begin{tabular}{lcccccc}
\hline \multirow{2}{*}{ Trait } & \multicolumn{2}{c}{ Males } & \multicolumn{2}{c}{ Females } & \multicolumn{2}{c}{ Sex differences } \\
\cline { 2 - 7 } & Mean & S.D. & Mean & S.D. & F ratio & Sign. ${ }^{*}$ P) \\
\hline Finger RC, I-r & 21.96 & 4.91 & 20.54 & 4.45 & 4.86 & $\mathbf{0 . 0 3}$ \\
\hline Finger RC, II-r & 12.82 & 5.96 & 14.08 & 6.26 & 2.43 & 0.12 \\
\hline Finger RC, III-r & 14.56 & 4.82 & 14.77 & 5.14 & 0.10 & 0.75 \\
\hline Finger RC, IV-r & 15.78 & 5.11 & 15.36 & 5.01 & 0.37 & 0.54 \\
\hline Finger RC, V-r & 13.97 & 4.57 & 13.78 & 4.71 & 0.09 & 0.77 \\
\hline Finger RC, I-I & 21.50 & 4.77 & 19.48 & 4.36 & 10.55 & $\mathbf{0 . 0 0}$ \\
\hline Finger RC, II-I & 13.17 & 5.61 & 13.51 & 5.89 & 0.18 & 0.67 \\
\hline Finger RC, III-I & 14.86 & 5.04 & 14.59 & 5.68 & 0.14 & 0.70 \\
\hline Finger RC, IV-I & 16.14 & 5.37 & 15.29 & 5.50 & 1.35 & 0.25 \\
\hline Finger RC, V-I & 15.40 & 4.80 & 14.41 & 4.70 & 2.24 & 0.14 \\
\hline Total RC & 154.36 & 38.02 & 144.20 & 41.37 & 4.03 & $\mathbf{0 . 0 5}$ \\
\hline Absolute RC & 215.93 & 79.58 & 201.04 & 76.30 & 2.12 & 0.15 \\
\hline PII, Ih & 7.31 & 1.82 & 7.55 & 1.63 & 1.00 & 0.32 \\
\hline PII, rh & 7.43 & 1.77 & 7.41 & 1.45 & 0.01 & 0.93 \\
\hline PII, both h & 14.72 & 3.42 & 15.03 & 2.80 & 0.47 & 0.50 \\
\hline a-b RC, rh & 39.06 & 7.18 & 39.59 & 6.59 & 0.39 & 0.53 \\
\hline a-b RC, Ih & 40.53 & 6.74 & 41.81 & 6.33 & 2.60 & 0.11 \\
\hline A-line exit I & 4.11 & 0.87 & 4.33 & 0.79 & 4.36 & $\mathbf{0 . 0 4}$ \\
\hline A-line exit r & 4.11 & 0.96 & 4.03 & 0.93 & 0.43 & 0.51 \\
\hline D-line exit I & 4.30 & 1.42 & 3.87 & 1.43 & 6.11 & $\mathbf{0 . 0 1}$ \\
\hline D-line exit r & 5.00 & 1.30 & 4.64 & 1.48 & 4.99 & $\mathbf{0 . 0 3}$ \\
\hline Main line index & 8.79 & 1.76 & 8.39 & 1.69 & 3.01 & 0.08 \\
\hline
\end{tabular}

* The differences are statistically significant when $\mathrm{P}<0.05$ 
reveal homogeneous character in nature. These results are similar to earlier studies in various populations (see among others, Reddy \& Malhotra 1985, 1987, Arrieta et al. 1990, Demarchi et al. 1997, Gomez \& Martin 1992, Karmakar et al. 2002, 2006, 2007, 2010). This difference between palm and finger may be due to the possible role of the environmental (prenatal) factors in the realization of the dermatoglyphic sex difference. The development of palmar dermatoglyphics has a relatively longer growth period compared with fingers (Cummins 1929). Thus, the palmar dermatoglyphic pattern of affinities corresponds better than fingers to the ethno- historic background of the populations (Reddy et al. 1988, Karmakar et al. 1989, 2002).

\section{REFERENCES}

1. Arrieta M. I., Ibrarrondo M. A., Lostao C. M. (1987). Digital dermatoglyphics in the Basque population: Univariate and multivariate comparison with other Spanish populations. Am J Phys Anthrop 73, 89-98.

2. Arrieta M. I., Martinez B., Simson A., Salazar L., Criado B., Lostao C. M. (1990). Quantitative and qualitative finger dermatoglyphics in the Basque valley of Urola, Spain. Anthrop Anz 48, 65-84.

3. Bat-Miriam Katznelson M., Ashbel S. (1973). Dermatoglyphics of Jews. 1. Normal Ashkenazi population Z Morph Anthrop 65, 14-28.

4. Bonnevie K. (1924). Studies on papillary pattern human finger. J Genet 15: 1-12.

5. Chakraborty R., Mathew S., Satyanarayana M., Majumder P. P. (1982). Inheritance of digital arches in humans: is major gene fully penetrant? Am J Anthrop $58,431-71$.

6. Cummins H., Midlo C. (1927). Dermatoglyphics in Jews. Am J Phys Anthrop 10, 91-113.

7. Cummins H. (1929). The topographic history of the volar pads (walking pads, tast ballen) in the human embryo. Embryol 20, 103-126.

8. Cummins H., Midlo C. (1961). Finger prints, palms and soles. Dover Publ. New York.

9. Crawford M. H., Duggirala R. (1992). Digital dermatoglyphic patterns of Eskimo and American populations: Relationships between geographic, dermatoglyphic, genetic and linguistic distances. Hum Biol 64, 683-704.

10. Demarchi D. A., Giordano A. R., Marcellino A. (1997). Dermatoglyphics in Araucanian Indians from Patagonia and multivariate comparisons with other Argentinian aboriginal populations. Hum Biol 69, 227-239.

11. Devi S. (2000). Mode of inheritance of finger and palmar dermatoglyphic patterns in an endogamous population of Orissa. Ph.D. Thesis, Utkal University, India. 
12. Dittmar M. (1994). Qualitative and quantitative analysis of digital and palmar dermatoglyphics in Chilean Aymara Indians. Anthropologia Biologica 2, 39-58.

13. Froehlich, J. W., Giles E. (1981). A multivariate approach to finger prints variation in Papua New Guinea: Perspectives on the evolutionary stability of dermatoglyphic markers. Am J Phys Anthropol 54, 93-106.

14. Geipel G. (1941). Die Gesantalage der finger leisten als neuea Merimal Zur Zwillings diagnose. Ibid 39, 414-419.

15. Gomez P., Martin J. (1992). Dermatoglyphic analysis of La Liebana (CantabriaSpain). 1- Fingertip patterns and pattern intensity index. Coll Antropol 16, 395403.

16. Herskovitz I. (1985). The effect of mating type on growth and development of children in South Sinai Bedouin Isolates. Ph.D. Thesis. Tel Aviv University, Israel.

17. Holt S. B. (1959). The correlations between ridge count on different fingers estimated from a population sample. Ann Hum Genet 23, 459-460.

18. Holt S. B. (1968). The genetics of dermal ridges. CC. Thomas, Springfield (III).

19. Jantz R. L., Eriksson A. W., Brehme H. (1993). Population relationships of Lapps as reflected by quantitative dermatoglyphics. Hum Biol 65, 711-730.

20. Karev G. B. (1991). Hypothener radial arch in man: Observations on its distribution, morphology, symmetry and inheritance. Am J Phy Anthrop 84, 479-487.

21. Karmakar B., Malhotra K. C., Narain P. (1989). Palmar dermatoglyphic distance analysis among 20 Dhangar castes of Maharashtra, India. Anthropologie 27, 1328.

22. Karmakar B., Yakovenko K., Kobyliansky E. (2002) Sexual dimorphism: 22 dermatoglyphic traits in five endogamous populations of West Bengal, India. In: Papers on Anthropology. Tartu University, Estonia. XI, 93-112.

23. Karmakar B., Yakovenko K., Kobyliansky E. (2005). Complex segregation analysis of quantitative dermatoglyphic traits in five Indian populations. Ann Hum Biol 32, 445-468.

24. Karmakar B., Yakovenko K., Kobyliansky E. (2006). Mode of inheritance of dermatoglyphic pattern intensity index on fingers in five Indian populations: A comparative study between individual trait and its factor. Am J Hum Biol 18, 377386.

25. Karmakar B., Yakovenko K., Kobyliansky E. (2007). Qualitative finger and palmar dermatoglyphics: Sexual dimorphism in the Chuvashian population of Russia. Anthrop Anz 65, 383-390.

26. Karmakar B., Yakovenko K., Kobyliansky E. (2008). Quantitative digital and palmar dermatoglyphics: Sexual dimorphism in Chuvashian population of Russia. Homo 59, 317-328.

27. Karmakar B., Kobyliansky E. (2010). Qualitative and quantitative finger and palmar dermatoglyphics: Sexual dimorphism in the Turkmenian population. In: Research in Physical Anthropology: Essays in honor of Professor L. S. Penrose, S. 
Datta Banik (edit), unas Letras industria editorial Publ, Merida, Yucatan, Mexico, page 115-145, Chapter 6.

28. Karmakar B., Malkin I., Kobyliansky E. (2011). Inheritance of 18 quantitative dermatoglyphic traits based on Factors in MZ and DZ twins. Anthrop Anz 68, 185-193.

29. Kobyliansky E., Livshits G. (1986). Anthropometric multivariate structure and dermatoglyphic pecuiliarities in biochemically and morphologically different heterozygous groups. Am J Phys Anthrop 70, 251-263.

30. Kobyliansky E. (1990). Gene pool as evidence of environmental adaptation of human populations: Based on biochemical, dermatoglyphic, morphological likeness and differences of the Jewish populations of the world. Hum Ecol 9, 37-62.

31. Kobyliansky E., Micle S. (1986). Finger patterns characteristics as determinants of total ridge count variability. Int J Anthropol. 1, 49-58.

32. Kobyliansky E., Micle S. (1987). Dermatoglyphic sexual dimorphism in Middle Eastern Jews. Bull. et Mem de la soc d'Anthrop. De Paris t 4, ser. XIV, no. 4, 271290.

33. Kobyliansky E., Micle S. (1988). Dermatoglyphic sexual dimorphism in North African Jews. Int J Anthropol. 3, 77-91.

34. Kobyliansky E., Micle S. (1989). Dermatoglyphic sexual dimorphism in East European Jews. Bull. et Mem de la soc d'Anthrop. de Paris t 1, no. 1-2, 13-36.

35. Matsuda F. (1973). Genetic studies on total finger ridge count among Japanese. Jap J Hum Genet 17, 293-318.

36. Mavalwala J. (1962). Correlations between ridge counts on all digits of the Parsis of India. Ann Hum Genet 26, 137-138.

37. Newman H. H. (1930). Palmar dermatoglyphics of twins. Am J Phys Anthrop.14, 331-378.

38. Penrose L. S., Ohara P. T. (1973). The development of epidermal ridges. J Med Genet 10, 201-208.

39. Pereira. M., Petit-Maire N., Jagolnitzer E. R. (1977). Dermatoglyphes digitaux et palmaries d'lsraelines. Bull. Et Mem. De la Soc. D’Anthrop. De Paris, a) 4, 2, 149164 , b) 4, 3, 245-263.

40. Reddy B. M., Malhotra K. C. (1985). Genetic significance of the relationship between total finger ridge count and its variability: Indian data. Homo 36,11-26.

41. Reddy B. M., Malhotra K. C. (1987). Genetic significance of the relationship between absolute total finger ridge count and its variability. Int J Anthropol 2, 141-149.

42. Reddy B. M., Chopra V.P., Karmakar B., Malhotra K. C. (1988). Quantitative palmar dermatoglyphics and the assessment of population affinities: Data from marine fishermen of Puri, India. Anthropol Anz 46, 235-244.

43. Rothhammer F., Chakraborty R., Liop E. (1977). A collation of gene and dermatoglyphic diversity at various levels of population differentiation. Am J Phys Anthrop $46,51-59$. 
44. Sachs, Bat-Miriam M. (1957) The genetics of Jews populations.1. Fingerprint pattern in Jewish populations in Israel. Am J Hum Genet 9, 117-126.

45. Sengupta M., Karmakar B. (2004). Mode of inheritance of finger Dermatoglyphic traits among Vaidyas of West Bengal, India. Ann Hum Biol 31, 526-540.

46. Singh S., Attkin M. A., Westwood N.H. (1977). Structural analysis of the ridge count data of Australian Europeans using multivariate analysis. Acta Genet Med Gemell 26,167-171.

47. Singh R. D. (1985). Digital ridge count variation in some castes of India. In: Progress in Dermatoglyphic Research. Barsocas CS (Ed). New York, 303-315.

\section{Address for correspondence:}

Dr. Bibha Karmakar

Biological Anthropology Unit

Indian Statistical Institute

203 B.T. Road, Kolkata 700 108, India

E-mail: bibha@isical.ac.in 